\title{
The nursing care system from a Luhmannian perspective
}

\author{
Dirce Stein Backes ${ }^{1}$ \\ Marli Stein Backes ${ }^{2}$ \\ Camila Biazus Dalcin ${ }^{3}$ \\ Alacoque Lorenzini Erdmann ${ }^{4}$
}

Objective: to investigate the socially-relevant communication of the nursing system from the Luhmannian perspective. Method: the investigation process was based in grounded theory. The data was collected between February and September 2011, through interviews carried out with nurses and student nurses at a university in the South of Brazil. Results: The central phenomenon - recognizing nursing care as an all-embracing interactive and associative phenomenon - resulted from the inter-weaving of three categories: learning the context of care as a whole, organizing the environment for the other professionals, and visibilizing interactive and associative care. Conclusion: investing in a socially relevant communication for nursing entails developing a code for functional differentiation, which may strengthen health promotion and healthy living for individuals, families and communities.

Descriptors: Nursing Care; Nurse's Role; Social Responsibility; Nursing Research.

${ }^{1} \mathrm{PhD}$, Professor, Centro Universitário Franciscano, Brazil.

2 PhD, RN, Hospital Escola, Universidade Federal de Pelotas, Brazil.

3 Undergraduate student in Nursing, Centro Universitário Franciscano, Brazil.

${ }^{4} \mathrm{PhD}$, Full Professor, Universidade Federal de Santa Catarina, Brazil. 


\section{Sistema de cuidado de enfermagem na perspectiva luhmanniana}

Objetivo: conhecer a comunicação socialmente relevante do sistema de enfermagem sob a perspectiva luhmanniana. Método: o processo de investigação foi baseado na teoria fundamentada nos dados. Os dados foram coletados entre fevereiro e setembro de 2011, por meio de entrevistas realizadas com enfermeiros e estudantes de enfermagem de uma universidade do Sul do Brasil. Resultados: o fenômeno central - reconhecendo o cuidado de enfermagem como um fenômeno abrangente, interativo e associativo resultou do entrelaçamento de três categorias: apreendendo o contexto de cuidado como um todo, organizando o ambiente para os outros profissionais e visibilizando o cuidado interativo e associativo. Conclusão: apostar em uma comunicação socialmente relevante para a enfermagem implica o desenvolvimento de um código de diferenciação funcional, que potencialize a promoção da saúde e o viver saudável de indivíduos, famílias e comunidades.

Descritores: Cuidados de Enfermagem; Papel do Profissional de Enfermagem; Responsabilidade Social; Pesquisa em Enfermagem.

\section{Sistema de cuidado de enfermería en la perspectiva luhmanniana}

Objetivo: conocer la comunicación socialmente relevante del sistema de enfermería en la perspectiva luhmanniana. Método: el proceso de averiguación fue basado en la teoría fundamentada en los datos. Los datos fueron colectados entre febrero y septiembre de 2011, por medio de entrevistas realizadas con enfermeros y estudiantes de enfermería de una Universidad del Sur de Brasil. Resultados: El fenómeno central - reconociendo el cuidado de enfermería como un fenómeno abarcador, interactivo y asociativo, resultó del entrelazamiento de tres categorías: aprehendiendo el contexto de cuidado como un todo; organizando el ambiente para los otros profesionales y percibiendo un cuidado interactivo y asociativo. Conclusión: apostar en una comunicación socialmente relevante para la enfermería implica en desarrollar un código de diferenciación funcional, que potencie la promoción de la salud y vivirlo saludable de individuos, familias y comunidades.

Descriptores: Atención de Enfermería; Rol de la Enfermera; Responsabilidad Social; Investigación en Enfermería.

\section{Introduction}

The system of nursing care has developed during its process of professionalization through the code of health-illness differentiation which is predominant in the present health system. In this relationship, however, the socially-relevant communication is the illness, and the focus of attention is the curative actions ${ }^{(1-2)}$.

The discussion about the health-illness code of differentiation was initially proposed by the German sociologist Niklas Luhmann, with the Theory of Social Systems. For the different social systems, from a Luhmannian perspective, communication is an element of the system's affirmation and functional identification, that is, in an instrument which is fundamental in the evolutionary dynamic of functionally differentiated systems. In this sense, the communication is developed through the production of informative content and the diffusion and acceptance of the same ${ }^{(3-5)}$.

For Luhmann, communication is processed through a code of differentiation, responsible for the production of information and in the identification of noises, in the form of simgular information. According to this understanding, the system determines what may be communicated through the code and, consequently, what must be selected from the surroundings. Thus, the functional differentiation code is centered in responding to the contingencies of the surroundings, and when this 
is not possible, the system needs to create a new code capable of meeting the functional complexity ${ }^{(3,6)}$.

For a specified social system to be functionally differentiated, it needs to ensure its own communication through a binary code. The system needs to develop a code for distinguishing between two communicative possibilities - such as, for example, the health-illness code, which identifies the health system and enables it to create new communications ${ }^{(4)}$.

Even though initial and partial, the discussion around this issue has already stimulated various enquiries between German sociologists and nurses and, recently, among professional nurses in Brazil too. Faced with the complexity of the milieu, scholars in the area have increasingly sought to develop a functional differentiation code which is specific to the area of nursing, a code whose socially-relevant communication should be healthy living in individuals, families and communities $^{(7-10)}$.

This investment is justified, in the Brazilian context, by the need to re-think the health care model and to propose references which are synchronized with the Unified Health System's principles and guidelines*. Focusing on primary care, the Unified Health System (UHS) transcends the traditional medical-curative model, through its broadened understanding of the health-illness process and the centrality of healthy living for individuals, families and communities. Thus, based in the rationale presented, one may ask: Is it possible to think a specific code for nursing, which is not the traditional health-illness code predominant in the health system, whose socially-relevant communication is illness? What is the nursing system's socially-relevant communication, and what distinguishes it from the other social systems?

The present study aimed to investigate the nursing system's socially-relevant communication from the Luhmannian perspective, so as to continue the discussions already begun and to viabilize the construction of a code specific to nursing, which might transcend the traditional health-illness code predominant in the present health system.

\section{Methodology}

The investigative process was based in grounded theory, which aims to identify, develop and relate concepts based in the data, which has been collected, analyzed and compared in a systematic, concomitant way. The development of a theoretical framework denotes a set of categories, constructed based on emerging issues and concepts which indicate relationships which are capable of forming a theoretical explanatory landmark of a social phenomenon $^{(11-12)}$.

The data was collected between February and September 2011, through interviews undertaken with nurses directly involved in care (N), nurse lecturers (NI), and nursing students (Ns). All the participants, after being informed of the research's method and objectives, signed the Terms of Free and Informed Consent, and were guaranteed free access to the data collected. The participants were also informed that their names would not be divulged and that they could withdraw from the study at any time without restrictions. The project was submitted to the Federal University of Santa Catarina's Research Ethics Committee and was approved under number 052/07.

In compliance with the process of theoretical sampling, the first sample group was made up of five nurse lecturers who were members of the study and research group in social entrepreneurship in nursing and health at UNIFRA**. The interviews were based in the following questions: How do you perceive the nursing system? What differentiates the nursing system from other social systems?

The interviews were recorded and transcribed, and the data was organized and analyzed with the aim of identifying the empirical indicators defined as codes, based in the technique of comparative analysis.

The analysis of the data collected from the first sample group permitted the forming of initial properties and hypotheses which guided the formation of the second group, comprised of twelve nurses directly involved in care, members of the UNIFRA's center for discussion on management and leadership, and who worked in care provision in hospitals or in specialized health clinics. The question for the interviews was: in your workplace, what distinguishes you from the other health care professionals? Why? When? How?

The data from the second group served to deepen the theoretical model, strengthening the categories created with analysis of the first group's data and of the secondary data, and enabled supplementary information which indicated the characteristics of the nursing system in the context of the shaping of, and the scenarios of, practice. In this way, a third group of interviews was

* The Unified Health Service (UHS) is the Brazilian Public Health Service. Translator's note.

** Fransiscan University Center, Rio Grande do Sul. Translator's note. 
decided on, with ten students in the last semester of UNIFRA's nursing course. These were selected randomly from the institution's registers and were interviewed based on the following questions: Based on your training, how do you perceive the nurse's activities? What do you consider to be specific to nursing, and what distinguished nursing from the other professions?

The empirical data was analyzed based in the process of open, axial and selective coding(12). The codes were organized according to their respective similarities and differences, and were grouped into categories and subcategories.

A central category was defined, based on the analysis of the relationships between the categories, and after the structuring of the theoretical model which represents the connection between the categories and subcategories, the same was validated.
For the validation and explanatory description of the theoretical model constructed, it was presented to five of UNIFRA's nursing researchers. These evaluated the theoretical model and presented suggestions which were incorporated into this model.

\section{Results}

The theoretical model which is referent to the nursing system's socially relevant communication reflects that nursing possesses possibilities and potential which guarantee its functional differentiation in the health system. The circularity and integrality of nursing care are expressed in the systemic interactions and associations with the team, the patient, the family and the dynamic environment.

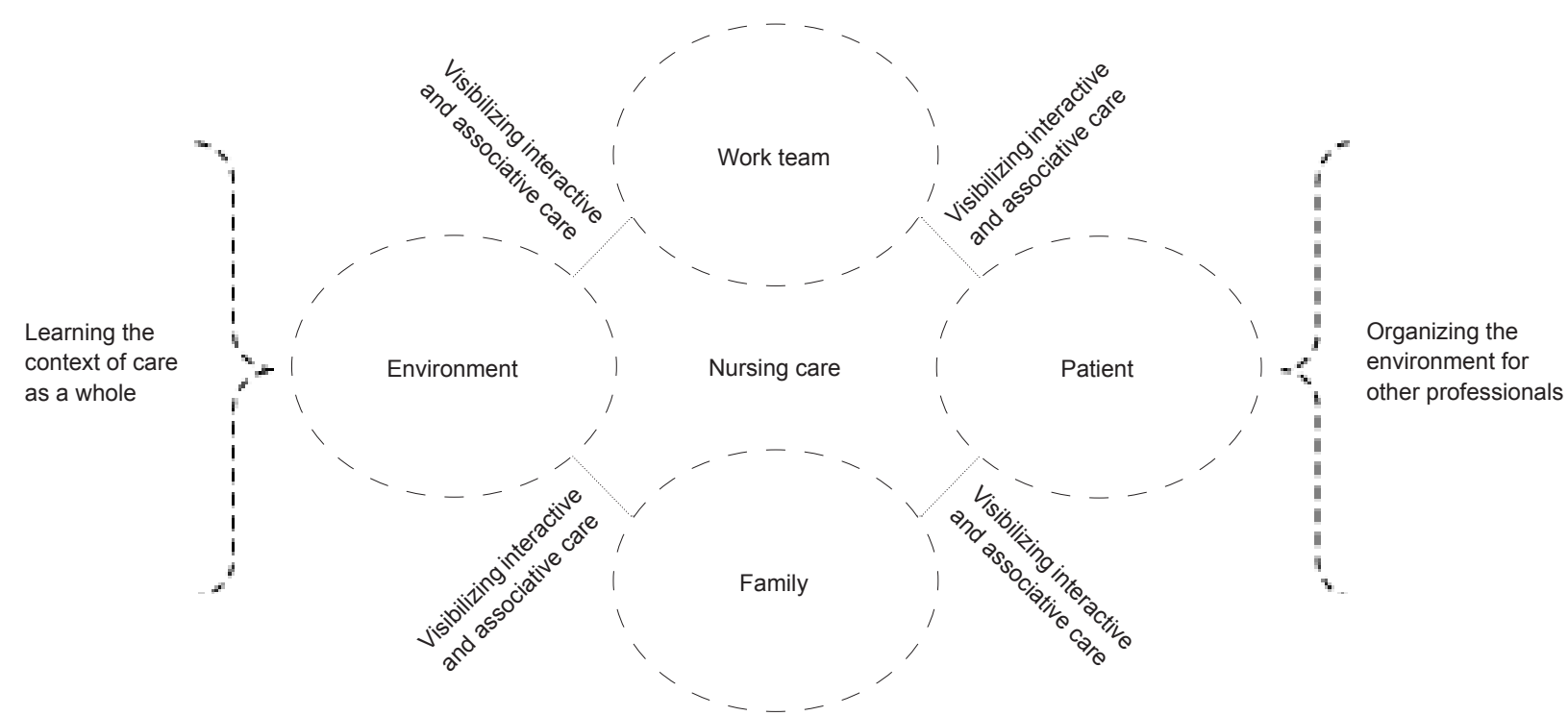

Figure 1 - Recognizing nursing care as a comprehensive, interactive and associative phenomenon.

The central phenomenon - Recognizing nursing care as a comprehensive, interactive and associative phenomenon - resulted from the integration of three categories: (I) Learning the context of care as a whole, (II) Organizing the environment for the other professionals, and (III) Visibilizing interactive and associative care. The content of each of these three categories, resulting from the organization and grouping of their respective codes and subcategories, will be presented below.

\section{Grasping the context of care as a whole}

The context of care is characterized as a selforganizing complex, which cannot be reduced to a formal institutionalized space, but which transcends the physical space and involves relationships, interactions and systemic associations.

Driven by professionals, service users and their family members, the context of care in health appears as a dynamic, self-feeding space. Woven together of various threads, the care moves continuously from the part to the whole and from the whole to the part. In this dialogical and circular relationship, the nurse is distinguished by her understanding and leadership of the whole, while the other health care professionals, frequently, are involved in or recognize only the part, as one of the participants specified in her comment: I think the doctor cares for only one part, the illness. Nursing cares 
for the whole. The nurse concerns herself even about where and with whom the mother in hospital has left her children... because the care involves the whole social network. (NI).

The understanding of the whole, understood as the nurse's socially relevant communication, can also be related to the capacity to transcend the linearity and materiality of health care. Such an assessment, not infrequently, creates discomfort and insecurity among nursing professionals, as they understand by it that their care has less impact than that of the other health care professionals, as in the comment: When we do the multiprofessional evaluation of the patients I have difficulty talking about the exact role of the nurse... each professional speaks about their part, while I speak about the whole. (N).

The nurse is to be found in all the places, deals with the different processes of care and takes into account the multiple dimensions and human relationships. However, the nurse frequently has difficulty in concretely visibilizing the object of her work. She perceives that the care is everything and that it is not always possible to decode it objectively, when compared to the work of the other health professionals. In this sense, the nursing care is expressed through sensitivity, interactivity and comfort. So many patients tell us that they have gone through great suffering and only found comfort in the nurse $(\mathrm{N})$. Thus, the nursing care is substantiated through individualized care for to each human being, based on human attitudes which transcend the linearity of specific actions.

\section{Organizing the environment for the other professionals}

Besides grasping and understanding the care as a whole, the nurse deals with, organizes, dynamizes and monitors the care environment for the other professionals. The nurse ensures that the environment should be clean, esthetic, well-lit and ventilated. She monitors the flow of people through the unit, as well as the appropriate use and maintenance of material and equipment. She fosters the integration of the work team and how it inter-relates with the other professionals involved in the care process. She intermediates in conflict situations, carries out referrals, and ensures the rapidity and organization of the work process.

Through her broad, interactive and intuitive view, the nurse perceives and easily becomes involved in the different movements which form part of the system's surroundings. Her way of thinking, managing and acting is related to the interconnectivity and interactivity with the patient, the family, the community and the team, twenty-four hours a day. In this process, the nurse does not care only for her functional part. This situation is well illustrated by the following comment: The nurse arranges everybody's life and doesn't leave anybody without an answer. When a doctor from the primary care center refers a patient to hospital, he doesn't speak to a medical colleague, he calls straight to a nurse, because he knows that straightaway she'll expedite and organize everything that's needed for complete care. (Ns).

Besides ensuring the organization and dynamicity of the care environment, the nurse also concerns herself with the system's surroundings, in the sense of processing new communications of meaning, as the following comment highlights: No other professional is so involved with the environment and everything that involves care, whether it's direct or indirect... the other professionals generally deal with a specific problem, their part, and then leave. (NI).

At the same time as the dynamization and organization of the care environment, along with the understanding of the system's surroundings, favor a widened, systemic nursing care, they also contribute to the invisibility of the specific nursing care. In this regard, nurses frequently ask themselves: what is, really, the object of the nurse's work? What is the nurse's identity? Why does the nurse involve herself in so many activities which are not directly related to the care specific to her? Why does the nurse feel responsible for everything and everybody?

The socially-recognized communication of the nurse, according to the interviewees, is related to the capacity to understand and manage health care in a way which is global, organized and safe. The nurse demonstrates that her role goes beyond the linear care based on specific actions, traditionally called for by the curative biomedical model.

\section{Visibilizing interactive and associative care}

Nursing care is recognized as broad, interactive and associative. Thus, it is frequently presented as an invisible, abstract care, principally in relation to the other health professionals' work object. This perception is even more visible in hospital institutions, where the principal focus of attention is the illness, and the centrality of the therapeutic process is the biological dimension.

This relationship is different in community health; in this space, health promotion and protection take priority, and the focus of attention involves broad, contextualized care. On this basis, the nurse stands out through her interactive and associative care, integrated with the social network: in hospital, the relevant communication is the illness, and in the community it's health promotion. As 
health promotion involves dealing with the family, education, transport, and questions related to electricity, water and the sewerage system the nurse does it well, because it's related to the whole social network. $(\mathrm{N})$.

Through her interactive skills and proximity, the nurse is able easily to identify the social needs of individuals, families and communities. She seeks to perceive and grasp the problems and human needs in a broad and contextualized way. The data demonstrates that the nurse identifies strongly with social questions. She can make out the needs in a much more practical way... she has the role of being responsible for health, rather than the illness. She uses the other professionals' arguments and tools for establishing complete care (NI).

Nursing has communicative characteristics which distinguish it from the other functionally-differentiated systems. In how she grasps, understands, dynamizes and leads health care, the nurse demonstrates that the object of her work transcends the materiality and the linearity of health care. Through its emphasis on global and systemic care, nursing demonstrates that it is capable of going beyond the illness or ill individual. It evidences, therefore, that it is possible to create new communications focused on healthy living, through appreciation of the human being as a unique and social being.

\section{Discussion: recognizing the part in the whole and the whole in the part}

To ensure the socially-relevant communication, by means of a code of functional differentiation, entails developing a distinction between two communicative possibilities which is capable of identifying the system and enabling it to create new communications ${ }^{(6)}$.

In this study, the distinction of the nursing system's communicative possibilities is expressed in two ways: through 'competencies for care as a whole' - 'noncompetencies for care as a whole' and 'competencies for health promotion and protection for individuals, families and community' - 'non-competencies for health promotion and protection for individuals, families and community'. This statement, which is in accordance with Hohm's ideas ${ }^{(7)}$, addresses discussions ${ }^{(7)}$ which refer to "competency for care - non-competency for care", which ensures the functional differentiation, without excluding the interactive and associative possibilities with the other professions.

While the nurse grasps, understands and dynamizes the care as a whole, the other health professionals limit themselves, frequently, to the care of the ill individual or the organ affected by the illness, for example the diseased liver or fractured limb. In relation to this, the nurse demonstrates that it is possible to learn the singular in the multiple and the multiple in the singular. This shows that the care is not limited to a linear, specific action, but that it encompasses the totality of the dimensions and movements which dynamize healthy living ${ }^{(1,13)}$.

Differently from the traditional and hegemonic code of health-illness, in which the focus of interest is the illness-ill individual, nursing is distinguished by the skills and competencies for understanding the multiple variables involved in the process of living healthily. In this sense, the nurse transcends the physio-pathological dimension of the illness and perceives the environment of care, in which multiple systemic relationships, interactions and associations move and interact(10,14).

From a Luhmannian perspective, the care environment or surroundings of the system are a condition for maintaining the systems' functional communication, considering that identity is only possible through differentiation(3). The nursing system, as it establishes interactions and associations with the other health professionals, does so based in the organization and dynamization of the care environment. This being so, the system is guided by its environment, not just in an occasional way and by selective adaptation, but in a special way through its interactive and adaptive competences.

The nursing system's differentiation does not mean independence from the other systems. As it is only partially capable of influencing healthy living in individuals, families and communities, Nursing needs to be interconnected with the other systems to ensure its socially-relevant communication. Thus, the interaction with the system's surroundings is indispensable to ensure its own functional differentiation ${ }^{(4-5)}$.

The construction of a code specific to nursing, transcending the traditional health-illness code of the present health system, whose focus is the illness, entails developing new communicative possibilities focused on the promotion and protection of health, as well as new opportunities for social insertion.

\section{Final considerations}

The present study reveals that Nursing possesses communicative possibilities and opportunities which distinguish it from the other functionally-differentiated 
systems, due to: learning the context of care as a whole, organizing the environment for the other professions, and visibilizing an interactive, associative care. Through its emphasis on systemic care, Nursing demonstrates that it is capable of going beyond the illness and creating new communications focused on the promotion and protection of health and the valorization of the human being as a singular and social being.

The results indicate the possibility of Nursing developing a specific binary code: a code which has as its focus care as a complex phenomenon, which encompasses the systemic interconnections with the team, the patient, the families, the community and the dynamic, changeable environment. This process, however, requires innovation, creativity, daring and the capacity to protagonize and visualize new spaces for professional performance.

This research suggests the limitations of qualitiative research, which is not intended to produce generalizations. As contributions to the nursing system, it is hoped that nurses might (re-)think the relational and assistential model and, as a consequence, develop strategies which consider healthy living as a sociallyrelevant communication, and the human being as a singular and social being, inserted in a complex and multi-dimensional reality.

Investing in a socially-relevant communication for the system of nursing entails, in short, developing a code of functional differentiation, which optimizes the promotion of health and is expressed in the systemic interactions and associations with the team, the patient, the family and the dynamic environment.

\section{References}

1. Backes DS. Vislumbrando o cuidado de enfermagem como prática social empreendedora [tese de doutorado]. Florianópolis (SC): Programa de Pós-Graduação de Enfermagem da Universidade Federal de Santa Catarina; 2008. 245 p.

2. Backes DS, Erdmann AL, Büscher A. Evidenciando o cuidado de enfermagem como prática social. Rev. Latino-Am. Enfermagem. 2009;17(6): 988-4.

3. Luhmann N. Soziale Systeme: Grundriß einer allgemeinen Theorie. Frankfurt: Main; 1984. 815 p.

4. Luhmann L. The autopoiesis of Social Systems. Sociocybernetic paradoxes. London (UK): BMJ Bo s/ Blackwells; 1996. 210 p.
5. Luhmann N. Sistemas Sociales. Lineamentos para una teoría general. México: Universidade Iberoamericana; 1998. $310 \mathrm{p}$.

6. Luhmann N. Der medizinische Code. In: Luhmann N. Soziologische Aufklärung: Konstrutivistische Perspektiven. Opladen: Westdeutscher Verlang; 1990. p. 183-5.

7. Hohm HJ. Das Pflegesystem, seine Organisationen und Karrieren. Systemtheoretische Beobachtungen zur Entstehung eines sekundären Funktionssystems. Freiburg: Lambertus; 2002. 320 p.

8. Schroeter KR. Das soziale Feld der Pflege: Eine Einführung in Strukturen, Deutungen und Handlungen. München: Juventa; 2006. 270 p.

9. Bauch J. Pflege als soziales System. In: Bauch J, editor. Gesundheit als System: Systemtheoretische Beobachtungen des Gesundheitswesens. Hartung-Gorre Verlang Konstanz; 2006. p. 139-50.

10. Backes DS, Backes MTS, Erdmann AL. Systemic social practice of nurses in luhmann's perspective. Rev Esc Enferm USP. 2011;45(1):116-21.

11. Corbin J, Hildenbrand B. Qualitative Forschung In: Allhoff R, Schaeffer D, editor. Handbuch Pflegewissenschaft. München: Juventa; 2003. p. 159-84. 12. Strauss A, Corbin J. Pesquisa qualitativa: técnicas e procedimentos para o desenvolvimento de teoria fundamentada. 2a ed. Porto Alegre (RS): Artmed; 2008 320 p.

13. Falcón GCS, Erdmann AL, Backes DS. Significados do cuidar na promoção da saúde. Rev. Latino-Am. Enfermagem. 2008;16(3):419-24.

14. Backes MTS. A sustentação da vida no ambiente complexo de cuidados em Unidade de Terapia Intensiva [tese de doutorado]. Florianópolis (SC): Programa de Pós-Graduação de Enfermagem da Universidade Federal de Santa Catarina; 2011. 320 p. 